\title{
Successful reuse of a transplanted kidney 9 years after initial transplantation: 4-year follow-up
}

\author{
Wen-Hsin Tseng ${ }^{1}$, Yu-Feng Tian ${ }^{2,3^{*}}$, Alex Chien-Hwa Liao ${ }^{4}$, Ming-Jenn Chen², Hsuan-Ying Ho ${ }^{1}$,
} Jinn-Rung Kuo ${ }^{5,6}$ and Steven K. Huang ${ }^{1}$

\begin{abstract}
Background: Kidney transplantation is the preferred renal replacement therapy for patients with end-stage renal disease, but the waiting list for kidneys continues to grow because of a shortage of donor organs. The reuse of transplanted kidneys would seem to be a good approach to expand the pool of available organs. Here, we describe the reuse of a kidney 9 years after the initial transplantation. At 4-year follow-up, the second recipient is showing good renal function.

Case presentation: In 2005, a kidney was transplanted from a 40-year-old man, who suffered brain death due to an intracranial hemorrhage, into a 45-year-old man. Nine years later, the recipient suffered a ruptured cerebral aneurysm, resulting in brain death. The kidney was re-transplanted into a 40-year-old man with diabetic nephropathy who had received hemodialysis for 5 years. During 4 years of follow-up, the graft has functioned well.

Conclusions: This case demonstrates the successful regrafting of a transplanted kidney. We believe this is the longest period for reuse of kidney after initial transplantation. The outcome suggests that a well-functioning transplanted kidney can be reused years after transplantation.
\end{abstract}

Keywords: Kidney transplantation, Reuse

\section{Background}

Despite the transplantation of kidneys from expanded criteria donors [1], the waiting list for kidneys continues to grow because of a shortage of donor organs $[2,3]$. In 1987, Al-Hasani et al. first reported the reuse of a transplanted kidney [4]. This seemed to offer a good approach for expanding the pool of available organs; however, the reuse of a transplanted kidney has rarely been attempted, with only around 10 cases reported [413]. Here, we describe a case in which a kidney was reused 9 years after the initial transplantation, probably the longest period after the initial transplantation for the

\footnotetext{
* Correspondence: cmh7590@mail.chimei.org.tw; b101096108@tmu.edu.tw ${ }^{2}$ Division of Transplantation Surgery, Division of General Surgery, Department of Surgery, Chi Mei Medical Center, Tainan, Taiwan

${ }^{3}$ Department of Health and Nutrition, Chia Nan University of Pharmacy and Science, Tainan, Taiwan

Full list of author information is available at the end of the article
}

reuse of a kidney. After 4 years of follow-up, the second recipient continues to show good renal function.

\section{Case presentation}

The first donor was a 40-year-old man who suffered brain death due to intracranial hemorrhage after a traffic accident. His terminal serum creatinine level was $0.8 \mathrm{mg} / \mathrm{dL}$ and his Kidney Donor Profile Index score was $27 \%$. The first recipient was a 45 -year-old man with a 20-year history of hypertension and end-stage renal disease (ESRD) due to hypertensive nephropathy, who had received regular hemodialysis for 2 years. In June 2005, at another hospital, single renal transplantation was performed in the right iliac fossa, with a cold ischemia time of $5 \mathrm{~h} 10 \mathrm{~min}$ and a warm ischemia time of $1 \mathrm{~h}$ $48 \mathrm{~min}$. After reperfusion, the recipient immediately passed urine. He was administered an immunosuppressive regimen comprising methylprednisolone, cyclosporine, everolimus, and mycophenolate mofetil, and he was

(c) The Author(s). 2018 Open Access This article is distributed under the terms of the Creative Commons Attribution 4.0 International License (http://creativecommons.org/licenses/by/4.0/), which permits unrestricted use, distribution, and 
discharged 10 days after the transplantation with a serum creatinine level of $1.4 \mathrm{mg} / \mathrm{dL}$. At regular followup over the next 6 months, his serum creatinine levels remained within the normal range.

Over the following 9 years, the recipient showed no episodes of rejection, and his serum creatinine levels and creatinine clearance rates were within the normal ranges (Fig. 1). In 2010, he underwent coronary percutaneous angioplasty and stent placement for coronary artery disease, and thereafter he regularly took aspirin. However, in June 2014, he suffered a right cerebral aneurysm rupture that resulted in brain death. At that time, his serum creatinine level was $0.94 \mathrm{mg} / \mathrm{dL}$ and the creatinine clearance rate was $90 \mathrm{~mL} / \mathrm{min}$. Before his death, the patient (while completely conscious) and his family had expressed a wish for his organs to be donated; we therefore harvested the transplanted kidney for reuse.

The second recipient of the kidney was a 40-year-old man with ESRD caused by diabetic nephropathy, who had been undergoing hemodialysis for 5 years and had been added to the waiting list for renal transplantation at that time. His blood group was the same as that of the initial donor and the first recipient (A rhesus positive). There were four human leukocyte antigen mismatches with the original donor and two with the second donor (Table 1). Crossmatching with the initial donor was not possible because of the long time that had elapsed since the initial transplantation, but crossmatching with the second donor was negative. A biopsy demonstrated the quality of the donated kidneys: the Remuzzi score was 1 and the Kidney Donor Profile Index score was $74 \%$.

Kidney transplantation was performed in June 2014, with a cold ischemia time of $4 \mathrm{~h} 12 \mathrm{~min}$ and a warm ischemia time of $1 \mathrm{~h} 12 \mathrm{~min}$. After transplantation, the recipient was administered an induction immunosuppressive regimen comprising basiliximab, high-dose methylprednisolone, and cyclosporine, subsequently shifted gradually to a maintenance immunosuppressive regimen comprising prednisolone, tacrolimus, everolimus, and mycophenolate mofetil. The second recipient was discharged 13 days after the transplantation, and his serum creatinine level was measured at follow-up every 3 months. As of June 2018, his renal function has remained stable, with a serum creatinine level of around $1.24 \mathrm{mg} / \mathrm{dL}$ (Fig. 1). There have been no episodes of rejection, and the patient has remained in a good clinical condition.

\section{Discussion and conclusion}

Kidney transplantation is an effective approach for patients with ESRD but is limited by the shortage of kidney donations. To address this, in 2003, the Board of Directors of the Organ Procurement and Transplantation Network/United Network for Organ Sharing adopted a new expanded criteria donor allocation policy for the USA, which defined an expanded criteria donor as any brain-dead donor aged $>60$ years or a donor aged > 50 years with any two of the following three conditions: a history of hypertension, a terminal serum creatinine level $\geq 1.5 \mathrm{mg} / \mathrm{dL}$, or death resulting from a cerebrovascular accident [1]. Studies have reported that patients who received a kidney from an expanded criteria donor experienced better outcomes than those who remained on dialysis therapy [14].

The most common cause of the loss of a kidney allograft is the death of a patient with a functioning graft $[11,15,16]$. In the 30 years since Al-Hasani et al. first reported the reuse of a transplanted kidney [4], there have been only 10 case reports of the reuse of a kidney [4-13]. Of the 10 initial recipients of these kidneys, six suffered brain death due to a massive intracranial

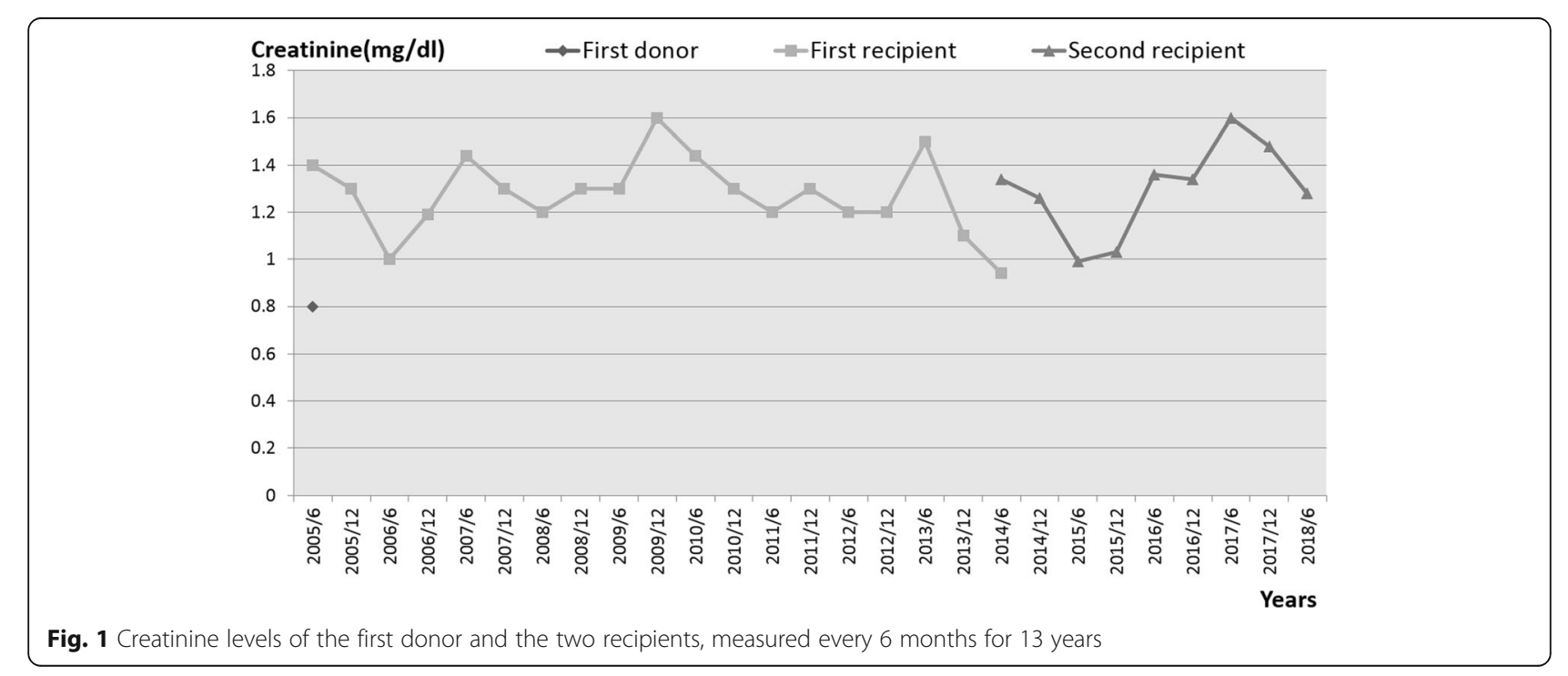


Table 1 Characteristics of the first donor and the two recipients

\begin{tabular}{|c|c|c|c|}
\hline & First Donor & First recipient/ Second donor & Second recipient \\
\hline Sex & Male & Male & Male \\
\hline \multicolumn{4}{|l|}{ Age (years) } \\
\hline Transplantation: & & 45 & 40 \\
\hline Death: & 40 & 54 & \\
\hline Cause of death & Intracranial hemorrhage & Ruptured cerebral aneurysm & \\
\hline Blood group & A positive & A positive & A positive \\
\hline \multirow[t]{5}{*}{ Human leukocyte antigen } & $\mathrm{A} 03$ & $\mathrm{~A} 11$ & A11 \\
\hline & A24 & - & A31 \\
\hline & B35 & B46 & B46 \\
\hline & B46 & B75 & - \\
\hline & DR01 & DR09 & DR08 \\
\hline
\end{tabular}

hemorrhage of unknown cause within 14 days after transplantation. Our case, with the first recipient experiencing 9 years of good renal function, is likely to have involved the longest period before the reuse of a kidney.

There has been speculation regarding the potential additive effects of repeated ischemia/reperfusion injury and the immunologic host response [5, 7]. Kidney grafts have been reused less frequently than liver grafts; this is mainly because liver transplantation is a lifesaving procedure for patients with end-stage liver disease, whereas some patients with ESRD have to remain on hemodialysis [13]. In the present case, however, the second recipient showed good renal and urinary functions immediately after the transplantation, and the graft has functioned well for 4 years.

The long-term outcome of kidney re-transplantation depends on several variables, including the kidney's exposure to repeated ischemia/reperfusion and brain stem death in two patients $[5,7]$. The outcome is likely to be less favorable than that for a kidney that is not being reused, which calls into question the appropriateness of offering such an organ for re-transplantation, as well as raising a number of ethical and scientific dilemmas [7]. Based on previous experience, we ensured the second recipient in this case was completely aware of the source of the kidney and the increased risk to which he would be exposed. As with other patients on the waiting list, our patient was willing to accept the risk of the surgery because he had been waiting for this opportunity for 5 years. Furthermore, the second donor and his family members seemed to have a strong understanding of the importance of organ donation, making them more prone to supporting the donation even of a previously transplanted organ. These observations may provide evidence for the ethical good of reusing organs for transplantation.

It is rare for a transplanted kidney to be reused, but such reuse may offer a viable option for increasing the pool of available organs. In the present case, a transplanted kidney was used 9 years after the initial transplantation; to the best of our knowledge, this is the longest period after the initial transplantation for the reuse of a kidney. The patient's renal function has remained good throughout 4 years of follow-up. Our results suggest that a transplanted kidney can be re-harvested if the second donor's renal function is normal.

\section{Abbreviation}

ESRD: End-stage renal disease

\section{Acknowledgements}

The author wishes to acknowledge the help of Ling-Hsien, Lee in data collection and grate to Dr. Tseng, Chien-Chang, Ying-Hsia, Shen for guidance.

Availability of data and materials

All data generated or analysed during this study are included in this published article.

\section{Consent for publication}

Written and informed consent for publication was obtained from the patient for herself.

\section{Authors' contributions}

WT, YT, AL provided clinical care; WT, YT, AL, MC, HH, JK, SH contributed to the final manuscript and approved it.

Ethics approval and consent to participate

This is a retrospective case report and no ethical approval was needed.

\section{Competing interests}

The authors declare that they have no competing interests.

\section{Publisher's Note}

Springer Nature remains neutral with regard to jurisdictional claims in published maps and institutional affiliations.

\section{Author details}

${ }^{1}$ Division of Urology, Department of Surgery, Chi Mei Medical Center, Tainan, Taiwan. ${ }^{2}$ Division of Transplantation Surgery, Division of General Surgery, Department of Surgery, Chi Mei Medical Center, Tainan, Taiwan. ${ }^{3}$ Department of Health and Nutrition, Chia Nan University of Pharmacy and Science, Tainan, Taiwan. ${ }^{4}$ Division of Urology, Division of Transplantation Surgery, Department of Surgery, Chi Mei Medical Center, Tainan, Taiwan. ${ }^{5}$ Division of Neurosurgery, Department of Surgery, Chi Mei Medical Center, Tainan, 
Taiwan. ${ }^{6}$ Department of Biotechnology, Southern Taiwan University of Science and Technology, Tainan, Taiwan.

Received: 19 June 2018 Accepted: 10 September 2018

Published online: 17 September 2018

\section{References}

1. Metzger RA, Delmonico FL, Feng $\mathrm{S}$, et al. Expanded criteria donors for kidney transplantation. Am J Transplant. 2003;3(Suppl 4):114-25.

2. Langone AJ, Helderman JH. Disparity between solid-organ supply and demand. N Engl J Med. 2003;349:704-6.

3. Levinsky NG, Rettig RA. The Medicare end-stage renal disease program. A report from the Institute of Medicine. N Engl J Med. 1991;324:1143-8.

4. Al-Hasani MK, Saltissi D, Chang R, et al. Successful regrafting of an explanted transplant kidney. Transplantation. 1987;43(6):916-7.

5. Bowman JS 3rd, Jaffers G, Waymack JP. Reutilization of a transplanted kidney--a case report. Transplantation. 1991;51(5):1124-5.

6. Andres A, Morales JM, Lloveras J. Reuse of a transplanted kidney. N Engl J Med. 1993;328(22):1644.

7. Graetz K, Cunningham D, Rigg K, et al. Expansion of the organ donor pool by the reuse of a previously transplanted kidney-is this ethically and scientifically valid? Transplant Proc. 2002;34(8):3102-3.

8. Celik A, Saglam F, Cavdar C, et al. Successful reuse of a transplanted kidney: 3-year follow-up. Am J Kidney Dis. 2007;50(1):143-5.

9. Kamar N, Rischmann P, Guilbeau-Frugier C, et al. Successful retransplantation of a kidney allograft affected by thrombotic microangiopathy into a second transplant recipient. Am J Kidney Dis. 2008; 52(3):591-4.

10. Goralczyk AD, Obed A, Lorf T. Fourteen-year survival of a renal graft reused 2 years after initial transplantation: a case report. Transpl Int. 2010;23(6):e15-7.

11. Kadambi PV, Chon WJ, Josephson MA, et al. Reuse of a previously transplanted kidney: does success come with a price? Clin Kidney J. 2012; 5(5):434-7.

12. Park SJ, Oh SH, Kang MS, et al. Reuse of a previously transplanted kidney from a deceased donor using Luminex virtual crossmatching: a case report. Transplant Proc. 2014;46(6):2083-5.

13. Lugo-Baruqui J, Burke GW, Guerra G, et al. Ten-year follow-up of a reused kidney graft for transplant using Sirolimus for maintenance immunosuppression. Transplant Proc. 2015:47(10):3027-30.

14. Pascual J, Zamora J, Pirsch JD. A systematic review of kidney transplantation from expanded criteria donors. Am J Kidney Dis. 2008;52(3):553-86.

15. West M, Sutherland DE, Matas AJ. Kidney transplant recipients who die with functioning grafts: serum creatinine level and cause of death. Transplantation. 1996;62(7):1029-30

16. Ojo AO, Hanson JA, Wolfe RA, et al. Long-term survival in renal transplant recipients with graft function. Kidney Int. 2000;57(1):307-13.

Ready to submit your research? Choose BMC and benefit from:

- fast, convenient online submission

- thorough peer review by experienced researchers in your field

- rapid publication on acceptance

- support for research data, including large and complex data types

- gold Open Access which fosters wider collaboration and increased citations

- maximum visibility for your research: over $100 \mathrm{M}$ website views per year

At $\mathrm{BMC}$, research is always in progress.

Learn more biomedcentral.com/submissions 